\title{
WHAT HEALTH INFORMATION IS NEEDED TO IMPROVE THE VACCINATION OUTCOMES OF COVID-19? : STUDY ANALYSIS IN COVID-19 VACCINATION IN SANGIHE ISLAND REGENCY, INDONESIA
}

\author{
Dhito Dwi Pramardika ${ }^{1 *}$, Jelita Siska Herlina Hinonaung ${ }^{1}$, Grace Angel Wuaten ${ }^{1}$, Astri Juwita \\ Mahidody ${ }^{1}$
}

${ }^{1}$ Politeknik Negeri Nusa Utara, Sulawesi Utara, Indonesia

*Correspondence email:dhitodwi@gmail.com

\begin{abstract}
The Indonesian government enforces a COVID-19 vaccination policy for all. Still, the achievement rate for the COVID-19 vaccination in Sangihe Islands Regency at the first dose is only 1.05\%, while the achievement at the second dose to date is only $0.47 \%$. With this in mind, the vaccination policy has not been in line with community participation. Therefore, this study aimed to determine what kind of health information is needed to increase the covid-19 vaccination rate. The method used in this research is a descriptive study with a purposive sampling technique which was held from January 7 to February 8, 2021, with a total sample of 85 respondents who are health workers in the Sangihe Islands Regency. The data analysis used is descriptive analysis with frequency distribution. The results in this study were $15.3 \%$ stated that they were not willing to vaccinate COVID-19 because $39 \%$ of COVID19 survivors, $38 \%$ had comorbidities, $15 \%$ were unsure of safety, and $8 \%$ feared side effects. Therefore, the conclusion of this study is to increase health information regarding vaccines for COVID-19 survivors, information about comorbidities such as what is appropriate for COVID-19 vaccination, safety, and side effects resulting from the COVID-19 vaccine.
\end{abstract}

Keywords: Health Information; Vaccination for COVID-19; Sangihe Island

\section{INTRODUCTION}

The number of COVID-19 cases globally as of April 26, 2021, was $146,841,882$, with $3,104,743$ deaths in these cases. Indonesia is ranked 24th globally for the most cases of COVID-19, with 1,641,194 cases (data on April 26, 2021). The number of cases is the same as $1.12 \%$ of the total cases in the world. The number of Case Fatality Rates for COVID-19 in Indonesia is $2.71 \% .^{1}$

The high number of cases made the government decide to take serious steps. The Indonesian government is trying to deal with this problem by making a policy, one of which is by vaccinating the people of Indonesia for COVID-19 per presidential regulation number 14 of 2021 concerning vaccine procurement and vaccination in the context of tackling the COVID-19 pandemic. ${ }^{2}$ This policy is because the government has determined that the COVID-19 pandemic is a non-natural disaster included in the national disaster category. ${ }^{3}$ This policy is the responsibility taken by the government, which is seen as a state-based economic perspective, namely placing itself as a center for national interests. $^{4}$

This policy came into effect in January 2021, starting with vaccination by the President of the Republic of Indonesia, which was then gradually carried out to health workers as a priority target. In stage 2 continued targeting public service workers and the elderly. After that, the target of the third stage was vulnerable people from economic, social and the final target is continued to the community and other economic actors based on the availability of vaccines. $^{5}$ 
The vaccination policy has not been in line with community participation. Facts in the field as of April 28, 2021, it is known that the national level of vaccination against COVID-19 for the first dose is only $30.11 \%$, while the vaccination for the second dose is $18.37 \%$. How are vaccinations done in border areas? Sangihe archipelago district is one of the regencies in North Sulawesi province, which directly borders the Philippines. The achievement rate for the first dose of vaccination is only $1.05 \%$, while the achievement in the second dose is only $0.47 \%$ so far. ${ }^{6}$

The low achievement is due to many hoaxes regarding vaccination that people in border areas also accept. In this district, not all regions have access to the internet network. Therefore, the most effective health information is done manually by word of mouth.

Efforts set by the government to improve these achievements are by imposing sanctions in the form of termination of social assistance, termination of government administration services, and even fines for targets who do not vaccinate $^{2}$. In addition to these efforts, an effective strategy is also needed to overcome these problems. Based on this, the research team is interested in knowing what kind of health information is required to increase the COVID-19 vaccination rate. This research can be used as a model in developing health education, especially for the community, especially in the Sangihe Islands Regency, in increasing the number of COVID-19 vaccination achievements.

\section{MATERIAL AND METHODS}

This research method is a descriptive survey. The population in this study was the people in the Sangihe Islands Regency. Health workers were chosen because they were the priority targets for the first stage, and then health workers would also be in charge of disseminating health information to the public. The sampling method used purposive sampling with the help of social media WhatsApp and used applications google forms to the questionnaire and questionnaires manually because some areas plagued the Internet network. This research activity was carried out for one month, from January 7 , 2021 , to February 8, 2021. The data analysis technique used was descriptive analysis with frequency distribution.

\section{RESULTS}

Table 1. Univariate test results

\begin{tabular}{|c|c|c|}
\hline Univariate & $\mathbf{N}(\mathbf{8 5})$ & $\%$ \\
\hline \multicolumn{3}{|l|}{ Age } \\
\hline 24-31 years & 46 & 54.1 \\
\hline $32-40$ years & 26 & 30.6 \\
\hline 41-49 years & 10 & 11.8 \\
\hline $50-58$ years & 3 & 3.5 \\
\hline \multicolumn{3}{|l|}{ Gender } \\
\hline Male & 24 & 28.2 \\
\hline Female & 61 & 71.8 \\
\hline \multicolumn{3}{|l|}{ Marital Status } \\
\hline Married & 63 & 74.1 \\
\hline Alone & 22 & 25.9 \\
\hline \multicolumn{3}{|l|}{ Religion } \\
\hline Protestant Christians & 70 & 82.4 \\
\hline Islam & 8 & 9.4 \\
\hline Catholic Christian & 7 & 8.2 \\
\hline \multicolumn{3}{|l|}{ Education Level } \\
\hline Diploma & 47 & 55.2 \\
\hline Bachelor & 10 & 11.8 \\
\hline $\begin{array}{l}\text { Bachelor and Profession } \\
\text { degree }\end{array}$ & 26 & 30.6 \\
\hline Master & 2 & 2.4 \\
\hline \multicolumn{3}{|l|}{ Occupation } \\
\hline Nurse & 65 & 76.5 \\
\hline Dental Nurse & 1 & 1.2 \\
\hline Midwife & 7 & 8.2 \\
\hline Epidemiologist & 4 & 3.5 \\
\hline Administration and Health & 4 & 4.7 \\
\hline \multicolumn{3}{|l|}{ Policy Personnel } \\
\hline Doctors & 5 & 5.9 \\
\hline \multicolumn{3}{|l|}{ Place of work } \\
\hline Department of health & 20 & 23.5 \\
\hline Community health center & 35 & 41.2 \\
\hline Hospitals & 28 & 32.9 \\
\hline Others & 2 & 2.4 \\
\hline \multicolumn{3}{|l|}{ Willingness to vaccinate } \\
\hline COVID & & \\
\hline Willing & 72 & 84.7 \\
\hline Not willing & 13 & 15.3 \\
\hline
\end{tabular}


A total of 85 respondents participated in this study. Most respondents in the age category 23-31 years as many as 46 respondents $(54.1 \%)$, with the most gender being women as many as 61 respondents (71.8\%). Respondents with married status were also the largest respondents in this study, with 63 respondents $(74.1 \%)$. The majority of religions of the respondent were Protestant Christians as many as 70 respondents (82.4\%), Diploma was the highest level of education among respondents, namely 47 respondents $(55.2 \%)$ with the type of work as nurses were the most significant respondents with 65 respondents $(76.5 \%)$. Then the most respondents were respondents who worked at the Community Health Center as many as 35 respondents $(41.2 \%)$.

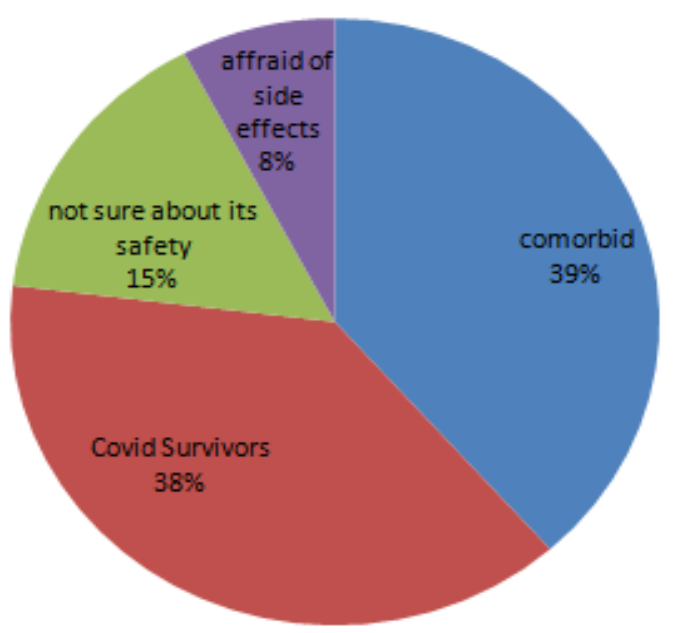

Figure 1. Reasons for not being willing

Based on figure 1 , it is known that $15.3 \%$ who were not willing to be vaccinated against COVID-19 stated that 39\% of them refused because they had been diagnosed with COVID-19, and $38 \%$ of respondents refused because they had comorbid diseases. Meanwhile, the remaining $15 \%$ are not sure about its safety, and the remaining $8 \%$ are afraid of the side effects.

Table 2. Comorbid diseases in respondents

\begin{tabular}{lll}
\hline Comorbid Diseases & N (5) & \% \\
\hline Hypertension & 2 & 40 \\
Diabetes melitus & 2 & 40 \\
Allergies & 1 & 20 \\
\hline
\end{tabular}

A total of the 85 respondents, five respondents, did not want to be given the COVID-19 vaccine because they had comorbid diseases. These comorbid diseases include hypertension (40\%), diabetes mellitus $(40 \%)$, and allergies $(20 \%)$.

Table 3. Information needed regarding COVID-19 vaccination

\begin{tabular}{lll}
\hline Type of information & $\mathbf{N}(\mathbf{8 5})$ & $\mathbf{\%}$ \\
\hline Vaccines for COVID-19 & 38 & 44.7 \\
Survivors & & \\
Comorbid & 37 & 43.5 \\
Safety of vaccines & 7 & 8.2 \\
Side effects of vaccines & 3 & 3.6 \\
\hline
\end{tabular}

Table 3 explains that 38 respondents (44.7\%) stated that they needed information about vaccines for those who had been exposed to COVID-19, 37 respondents $(43.5 \%)$ needed information about comorbid COVID-19, then seven respondents (8.2\%) needed information about the safety of the COVID-19 vaccine. Themselves and three respondents $(3.6 \%)$ said they needed information about the vaccine's side effects.

\section{DISCUSSION}

Compared with the results of a survey conducted by French $33.53 \%$, The United States $28.19 \%$, India $29.2 \%$, Vietnam $13.8 \%$, Singapore $4.6 \%$, and the Indonesia government, which amounted to $8 \%$ of rejecting the vaccine. ${ }^{7-9}$ The results of other surveys are not much different, which states that people's desire to be vaccinated is very low, namely $14.8 \% .{ }^{10}$ So the percentage of the results in this study was greater, which means that serious attention is needed to educate the COVID-19 vaccination. Then results of the vaccination results from the first dose and the second dose are still low in Sangihe District. It is necessary to carry out health promotion activities to change people's behavior in vaccination, namely by increasing predisposing, enabling, and reinforcing factors. Change someone's behavior. ${ }^{11}$

Knowledge is important in changing a person's behavior. In making efforts to increase knowledge in the community, a 
health promotion planning stage is needed through situation analysis, determining problem priorities, determining alternative problem solving, planning, and implementing. It so that the provision of health information is carried out to get maximum results ${ }^{12}$. But often, health promotion efforts are not carried out. Carry out these stages, which result in the goal of the health promotion activity not being achieved.

Respondents are health workers who are also included in the reinforcing factor. Health workers have an essential role in delivering health information, especially in the Sangihe district. Health workers are role models in the health sector who are respected by the community. So health workers should reflect on the value of health to build trust and adherence to the vaccination $\operatorname{program}^{13}$. Support for health workers who master health information can increase success in health promotion activities, in this case, the achievement of COVID-19 vaccination.

The health information needed to improve vaccination outcomes is first in the form of information about someone who has been diagnosed with COVID-19. From the results of data analysis, when someone has been diagnosed, there is no need to be vaccinated again. Based on the guidance from PAPDI, it is also stated that someone who has been diagnosed with COVID-19 is not recommended to be vaccinated against COVID-19 14 . This is because someone diagnosed with COVID-19 has already formed antibodies in that person ${ }^{15}$. But the latest information is currently in Indonesia that for COVID-19 survivors, vaccinations are still carried out if they have been declared cured with a period of more than three months. ${ }^{16}$ Based on the latest information, it is hoped that the public will understand more about vaccination because the latest regulations set by the government have gone through various stages and tests, so that it is safe to do so.

The next health information that is important in improving COVID-19 vaccination outcomes is comorbid. Many studies have been conducted on people who are positive for COVID-19. The result is that people suffering from the chronic disease have a higher risk of being infected with the SARS-CoV-2 virus and have a higher risk of dying after being infected ${ }^{17}$.This is from research conducted by a meta-analysis of 7 studies on severe degrees of COVID-19 which stated that COPD $(\mathrm{OR}=6.42)$, diabetes mellitus $(\mathrm{OR}=3.12)$, cardiovascular $(\mathrm{OR}=$ $2.70)$, and hypertension. $(\mathrm{OR}=1.97) .{ }^{18} \mathrm{In}$ another study conducted retrospectively on 487 COVID-19 subjects with a severe degree, it was also stated that age $\geq 50$ years, men with a history of hypertension were high-risk factors for experiencing COVID-19. ${ }^{19}$ Meanwhile, in another study regarding the mortality of COVID-19, diabetes mellitus, and cardiovascular disease are high-risk factors for the death of COVID-19 at the Bhakti Dharma Husada Hospital Surabaya. ${ }^{20}$ These respondents' information only slightly understands, even though the respondent is a health worker. Respondents 'unwillingness was due to the respondents' lack of information that they understood about comorbid. For these comorbid reasons, many misunderstandings are found due to the lack of information they get. So far, efforts to increase knowledge have only focused on efforts to prevent COVID-19 itself, so that information about comorbidity is not specifically explained. It was explained that people with hypertension can be vaccinated on the condition that hypertension is controlled $<140 / 90$ with or without drugs, as well as diabetes mellitus that vaccines can be done provided that people with type 2 diabetes mellitus are controlled and $\mathrm{HbA} 1 \mathrm{C}$ below 58 mmol or $7.5 \%$ can be given the vaccine. Meanwhile, people with food and drug allergies can also vaccinate COVID-19, except for some antibiotic drugs such as neomycin, polymyxin, streptomycin, and gentamicin which need major attention to the COVID-19 vaccine ${ }^{14}$. Recent information states that people with hypertension with a blood pressure reading of $<180 / 100 \mathrm{mmHg}$ can still be vaccinated, while for diabetes sufferers, vaccination is still carried out as long as there are no acute complications. Even 
the latest information also states that cancer and autoimmune sufferers may be vaccinated against COVID-19. ${ }^{21}$ Based on this, people who have comorbidities make themselves the priority for vaccination. ${ }^{22}$

The next information is in the form of the safety of the COVID-19 vaccine. Information that needs to be conveyed is that before this vaccine is given widely, such as Sinovac or Astra Zeneca, this vaccine must pass four stages of testing starting from the preclinical stage, namely the stage where the vaccine is given to animals such as mice and monkeys. Then proceed with the first phase of clinical trials, namely vaccines are given to dozens of people who will then be assessed for safety, dosage, and immune system stimulation. Then in the second phase of clinical trials involving hundreds of people who continue the first phase. Then it was carried out in the third phase of clinical trials on thousands of people to assess the vaccine's efficacy. The results of the various stages of the test were just accepted and deserved to be given widely. The result of the efficacy of the Synovac vaccine in Brazil was $78 \%$, in Turkey, it was $91.25 \%$, and in Indonesia, it was $65.3 \%$. Meanwhile, for Astra Zeneca, $90 \%$. $^{23}$

Important health information to be conveyed to the public to increase the vaccination rate is by providing information about the side effects experienced during vaccination. Many hoaxes are circulating in the community, so the explanation about this is very important to convey. Deddy Mulyana stated that the main factor of hoaxes spreading easily in Indonesia is the original Indonesian people's character. Indonesian people are considered not accustomed to different opinions. This condition is a factor in society swallowing the hoax without analyzing the source ${ }^{24}$. Research also states that hoax which has been widely spread and carried out repeatedly through social media can form a public perception or opinion that the news conveyed is true. ${ }^{25}$ Health information is required for behavior change. ${ }^{26}$

The side effects that are obtained are very diverse. It is due to differences in the condition of a person's body. ${ }^{27}$ The study results stated that for Sinovac, based on local reactions, there are two mild to moderate in nature, such as pain, induration, irritation, redness, and swelling. Then, based on the systemic effect, the resulting reaction experiences myalgia, fatigue, and fever. ${ }^{28}$ While the side effects resulting from Astra Zeneca are pain or pain when pressed at the injection site, headache, fatigue, muscle or joint pain, fever, chills, and nausea. ${ }^{29}$

\section{CONCLUSION}

This study concludes that four health information is most needed in improving the achievement of COVID-19 vaccination. Firstly, about vaccines for COVID-19 survivors, secondly about what kind of comorbid COVID-19 vaccination is worth, the third and fourth are the safety and side effects of the COVID-19 vaccine.

It is recommended that health workers promote activities for the four health information. If provided to the public, these four pieces of information are expected to increase public knowledge, which will result in an increase in participation rates for COVID-19 vaccination.

\section{REFERENCES}

1. WHO. Data Table WHO Coronavirus (COVID-19) [Internet]. 2021 [cited 2021 Apr 29]. Available from: https://covid19.who.int/

2. Menkumham RI. Perpres Ri Nomor 14 Tahun 2021. 2021;2019(84421):84421-30.

3. Keputusan Presiden RI. Keppres No 12 Tahun $2 \mathrm{O} 2 \mathrm{O}$ Tentang Penetapan Bencana Nonalam Penyebaran Corona Virus Disease 2019 Sebagai Bencana Nasional. Fundam Nurs. 2020;(1):1-2.

4. Akbar I. Vaksinasi Covid-19 dan Kebijakan Negara: Perspektif Ekonomi Politik. J Acad Praja. 2021;4(1):24454.

5. Kementerian Kesehatan Republik Indonesia. Question ( Faq ) Pelaksanaan Vaksinasi Covid-. 2021;1-16. Available from: 
https://kesmas.kemkes.go.id/assets/upl oads/contents/others/FAQ_VAKSINA SI_COVID_call_center.pdf

6. Kementerian Kesehatan Republik Indonesia. Vaksinasi COVID-19 (Data per Tanggal 29 April 2021 pukul 12.00 WIB) [Internet]. 2021 [cited $2021 \mathrm{Apr}$ 29]. Available from: https://vaksin.kemkes.go.id/\#/province S

7. Ritchie H, Ortiz-Ospina E, Beltekian D, Mathieu E, Hasell J, Macdonald B, et al. Statistics and Research Coronavirus (COVID-19) Vaccinations [Internet]. Our World in Data. 2021 [cited 2021 May 17]. Available from: https://ourworldindata.org/covidvaccinations?country=OWID_WRL

8. Chew NWS, Cheong C, Kong G, Phua K, Ngiam JN, Tan BYQ, et al. An AsiaPacific study on healthcare workers' perceptions of, and willingness to receive, the COVID-19 vaccination. Int J Infect Dis [Internet]. 2021;106:5260. Available from: https://doi.org/10.1016/j.ijid.2021.03.0 69

9. Kementerian Kesehatan Republik Indonesia, ITAGI, WHO, UNICEF. Survei Penerimaan Vaksin COVID-19 di Indonesia. Satuan Gugus Tugas Penanganan COVID-19. 2020;(November):1-26.

10. Ruiz JB, Bell RA. Predictors of intention to vaccinate against COVID19: Results of a nationwide survey. Vaccine. $2021 \quad$ February 12;39(7):1080-6.

11. Pramardika DD. Buku Ajar Promosi Kesehatan. Makasar: Yayasan Barcode; 2020.

12. Kurniati DPY. Buku Ajar Perencanaan Dan Evaluasi Program. Jurnal. 2016;40 hal.

13. Lazarus J V., Ratzan SC, Palayew A, Gostin LO, Larson HJ, Rabin K, et al. A global survey of potential acceptance of a COVID-19 vaccine. Nat Med [Internet]. 2021;27(2):225-8.
Available from: http://dx.doi.org/10.1038/s41591-0201124-9

14. PAPDI. Rekomendasi PAPDI Tentang Pemberian Vaksinasi Covid-19 [Internet]. papdi.or.id. 2020 [cited 2021 Apr 29]. Available from: https://www.papdi.or.id/berita/infopapdi/998-rekomendasi-papditentang-pemberian-vaksinasi-covid-19

15. Wib J, Ika O. Covid-19 Tidak Divaksin. 2021.

16. Kementerian Kesehatan Republik Indonesia. Kelompok Komorbid bisa Divaksinasi, Begini Ketentuannya [Internet]. 2021 [cited 2021 Apr 29]. Available from: https://www.kemkes.go.id/article/view /21021800001/kelompok-komorbidbisa-divaksinasi-beginiketentuannya.html

17. Verity R, Okell LC, Dorigatti I, Winskill P, Whittaker C, Imai N, et al. Estimates of the severity of coronavirus disease 2019: a modelbased analysis. Lancet Infect Dis. 2020;20(6):669-77.

18. Jain V, Yuan JM. Systematic review and meta-analysis of predictive symptoms and comorbidities for severe COVID-19 infection. medRxiv. 2020.

19. Shi Y, Yu X, Zhao H, Wang H, Zhao $\mathrm{R}$, Sheng J. Host susceptibility to severe COVID-19 and establishment of a host risk score: Findings of 487 cases outside Wuhan. Crit Care. 2020;24(1).

20. Satria RMA, Tutupoho RV, Chalidyanto D. Analisis Faktor Risiko Kematian dengan Penyakit Komorbid Covid-19. J Keperawatan Silampari. 2020;4(1).

21. KPCPEN. Vaksinasi COVID-19: Lampu Hijau untuk Kelompok Komorbid dan Penyintas [Internet]. Komisi Penanganan CoOVID-19 dan Pemulihan Ekonomi Nasional. 2021 [cited 2021 Apr 29]. Available from: https://covid19.go.id/berita/vaksinasicovid-19-lampu-hijau-untukkelompok-komorbid-dan-penyintas 
22. Ejaz H, Alsrhani A, Zafar A, Javed H, Junaid K, Abdalla AE, et al. COVID19 and comorbidities: Deleterious impact on infected patients. Vol. 13, Journal of Infection and Public Health. Elsevier Ltd; 2020. p. 1833-9.

23. Rengganis I. Vaksinasi COVID-19 [Internet]. Jakarta; 2021. Available from:

https://www.papdi.or.id/pdfs/999/Prof Iris Rengganis - Vacc COVID-19 Workshop 18 Januari 2021.pdf

24. Ahyad MRM. Analisa Penyebaran Berita Hoax Di Indonesia. Jurnal [Internet]. 2017;16. Available from: http://ravii.staff.gunadarma.ac.id/Publi cations/files/3552/ANALISIS+PENY EBARAN+BERITA+HOAX++DI+IN DONESIA.pdf

25. Juditha C. Interaksi Komunikasi Hoax di Media Sosial Serta Antisipasinya. J Pekommas. 2018;3(1):31-4.

26. Allegrante JP, Auld ME, Natarajan S. Preventing COVID-19 and Its Sequela: "There Is No Magic Bullet. It's Just Behaviors." Am J Prev Med [Internet]. 2020;59(2):288-92. Available from: https://doi.org/10.1016/j.amepre.2020. 05.004

27. Kemenkes. Buku Saku.Pdf [Internet]. Jakarta: Kementerian Kesehatan Republik Indonesia; 2020. Available from:

https://dinkes.jatimprov.go.id/userima ge/dokumen/Buku Saku.pdf

28. BPOM RI. Keamanan dan Efikasi Vaksin Covid-19. 2021;14. Available from: https://persi.or.id/wpcontent/uploads/2021/01/paparan_bpp om_rakernassus.pdf

29. WHO. Background paper on COVID19 vaccines Prepared by the Strategic Advisory Group of Experts (SAGE) on Immunization Working Group on COVID-19 vaccines. EuropeanreviewOrg [Internet]. 2020;(February):1-52. Available from: https://covid19.who.int/table 